\title{
A SYNOPSIS OF FIELD AND REMOTE SENSING BASED METHODS FOR STUDYING AFRICAN ELEPHANT (LOXODONTA AFRICANA) IMPACT ON WOODY VEGETATION IN AFRICA
}

\author{
NKosi, S. E..$^{1,2^{*}}$ - ADAM, E. ${ }^{1}-$ BARRETT, A. S. $^{2}-$ BROWN, L. R. $^{2}$ \\ ${ }^{I}$ School of Geography, Archaeology and Environmental Studies \\ University of the Witwatersrand, Private Bag X3 Wit 2050 Johannesburg, South Africa \\ ${ }^{2}$ Applied Behavioural Ecology and Ecosystem Research Unit \\ Department of Environmental Sciences, University of South Africa \\ Private Bag X6, Science Campus, 1710 Johannesburg, South Africa \\ *Corresponding author \\ e-mail:nkosise@unisa.ac.za \\ (Received 21 ${ }^{\text {st }}$ Nov 2018; accepted $28^{\text {th }}$ Jan 2019)
}

\begin{abstract}
African elephants (Loxodonta africana) negatively influence woody vegetation, causing structural changes to ecosystems. Field-based survey methods used to monitor elephant impact, while valuable, are costly and time-consuming to execute. By applying distance-sampling techniques such as remote sensing technology, inaccessible areas can be surveyed. This overview provides insight into methods used by scientists to determine the impact of elephants on woody vegetation in sub-Saharan Africa. Data were sourced from a variety of research databases. Findings indicate that $87 \%(n=92)$ of the reviewed studies used field-based methods and $13 \%(n=14)$ used remote sensing-based methods. We explore the national affiliations of the lead and the last authors of the reviewed studies and the scientific journals that published them. Field-based is the dominant method used in the majority of published studies on elephant impact. The majority of these studies were published in European and American journals, instead of African journals, which are less represented. However, the majority of the lead and last authors' affiliations for both field-based and remote sensing based methods are affiliated with African institutions. We conclude that there is a need to improve the integration of remote sensing techniques into conservation and other ecological fields.
\end{abstract}

Keywords: savanna, satellite imagery, national affiliation, accessibility, reviewed studies

\section{Introduction}

African elephants (Loxodonta africana) are found in sub-Saharan Africa (Blanc et al., 2007), where they occupy savanna ecosystems, dense forests, Sahelian scrub and deserts (Nowak, 1999). Based on genetic information, taxonomists suggest that there are two sub-species of the African elephant namely, the forest elephant and the savanna elephant. Current literature indicates that there is no detailed knowledge available on the distribution of these sub-species or the presence of potential hybrid populations (Mondol et al., 2015). Savanna elephants are predominantly found in eastern and southern Africa, while the forest elephants are found mainly in the Congo Basin of Central Africa (Thouless et al., 2016). In this study, we considered African elephant as a single species found in sub-Saharan Africa (East, Central, West and Southern Africa).

Elephants, in general, utilize a wide range of landscape types when foraging. The distribution of resources across landscapes influences elephant home range use and size. Individual home ranges may include a variety of landscapes and ecosystems (Grainger et al., 2005). A home range is defined as an area traversed by an individual in its normal activities of food gathering, mating and caring for young (Burt, 1943). Elephant feeding 
behavior, densities, interactions with other herbivores, associated ecological and environmental factors such as fire damage, rainfall patterns, and plant growth rates, all influence elephant impact on vegetation (Dublin et al., 1990; Ben-Shahar, 1996b; Ferguson, 2014).

Adverse impacts associated with African elephants on ecosystems include reducing tree heights and densities, which leads to structural changes in the woody layer (BenShahar, 1998; de Boer and Kohi, 2008). Changes in overall vegetation composition lead to a decline in biodiversity (Kelly, 2000). Guldemond (2006) found that elephant impacts in closed woodlands create canopy gaps, leading to reduced recruitment of young trees. Elephants require a daily average fresh food intake of approximately $173 \mathrm{~kg}$ across both the wet and dry seasons (Ruggiero, 1992). Since they feed mainly on woody plants, tree mortalities are common in areas they frequent. Woody plant species composition, tree species distribution, tree size, tree age, feeding preferences and habitat availability influences the consumption of woody vegetation by elephants (Gadd, 2002; Van Staden et al., 2016).

Protected areas are representative of natural vegetation that previously occurred in the broader vicinity around the protected area. This includes woodland spatial distribution, composition, and structure without anthropogenic influences (Guy, 1976; Gandiwa et al., 2011). The vegetation type, rainfall (Gandiwa and Kativu, 2009), management and conservation strategies and interventions (Hamandawana, 2012), differ for each protected area. Smit and Ferreira (2010) state that the availability and distribution of water sources remain different from one area to another, influencing elephant movement patterns. Variability between areas and their sizes, coupled with different elephant densities leads to fluctuating distribution patterns and intensities of elephant impact. The numbers of elephants have been steadily increasing in many protected areas in the sub-Saharan region, raising concerns of their impacts to biodiversity (Van Aarde et al., 2006; Van Aarde and Jackson, 2007). The focus on elephant management in many protected areas has been on their numbers in relation to the size of the area they occupy. According to Van Aarde et al. (2006), this approach gave rise to the establishment of many artificial water points, which modify the movements and home ranges of elephants.

Available methods for managing elephant populations include culling, relocation, and the use of contraceptives (Pimm and Van Aarde, 2001; Rubio-Martínez et al., 2014). Elephant culling remains a highly debated and sensitive subject in the scientific community (Mackey et al., 2006; Balfour et al., 2008; Lotter et al., 2008). Relocation of elephants is not a permanent option, but a temporary solution that can present adverse effects on the breeding behavior of female elephants (Raath, 1999). Relocated animals that breed can often not be accommodated by the parks or reserves they are moved to (Rubio-Martínez et al., 2014). Laparoscopic vasectomy is a costly contraceptive technique applicable to free-ranging male elephants. The long-term effects of this type of contraception are yet to be studied to determine how the elephant population demographics and dynamics are influenced (Rubio-Martínez et al., 2014). Additional contraceptive techniques available to wildlife managers for free-ranging elephant cows include pregnancy termination, the use of estrogen implants and immunocontraception (Poole, 1993; Whyte and Grobler, 1998). While these contraceptive techniques reduce population growth rates, they are often impractical and expensive to implement (Whyte et al., 1998). 
An increase in the number of studies that investigates the impact of elephants on vegetation structure and dynamics has been noticed over the three past decades (BenShahar, 1996a, 1998; Shannon et al., 2011; Van Staden et al., 2016). Moreover, the impacts of elephants on vegetation has increasingly become one of the main concerns for environmental and protected area managers (Baxter and Getz, 2008; Wiseman, 2001). We identified two review papers on the impacts of elephants on vegetation in Africa (Guldemond and Van Aarde, 2008; Guldemond et al., 2017). Guldemond and Van Aarde (2008) reviewed 21 studies between 1961 and 2005 from 14 study sites in Africa. Although no opinion or broad generalizations were made on elephant management from the reviewed studies, there was no doubt that elephants have an effect on woody vegetation and that high elephant densities could result in adverse impacts. Guldemond and Van Aarde (2008) also highlighted the lack of published information on the effect of elephants on vegetation.

A current review paper by Guldemond et al. (2017) that looked at 51 peer-reviewed articles concluded that elephants have a significant influence on vegetation by changing tree structure and abundance. No overall adverse cascading effects for species that share space with elephants were reported. Both these reviews focus on the impact of elephants and not the methods applied. This makes it necessary to provide an overview of the studies and techniques that have been used to quantify the impacts of elephants on the environment. This would provide useful information for conservation managers, and would also identify opportunities for further research into practical and time-efficient methods for studying the impact of elephants on vegetation.

This paper aims to provide an insightful review of the types of methods used by different peer-reviewed studies to quantify and detect the impact of elephants on woody vegetation in sub-Saharan Africa from 1970 to 2017. For this paper, we grouped the studies into two different categories, a field-based (FB) approach and those that used a remote sensing-based (RS) approach. Field-based approaches involve the physical collection of detailed data using certain tools and techniques in the veld (Zimmerman, 2014). Remote sensing approaches provide a variety of imagery known for their different spectral, spatial, radioactive and temporal characteristics that are applicable for use in broad vegetation studies (Xie et al., 2008).

Our review provides information on the geographic location of each study (location of study area and spatial scale of research), the national affiliation of the lead and the last authors and whether the publication is local (within Africa) or international (outside the African continent). We further explore studies that use remotely sensed data in more detail and highlight the challenges and limitations of field-based and remote sensingbased methods.

\section{Materials and methods}

\section{Database and literature search}

For this review paper, we only included studies that related to the African elephant and made no distinction between forest and savanna elephants. We were interested in studies that explored the damage or impact of elephants on woody vegetation in conservation and protected areas. We have, therefore, excluded studies on immunecontraception, distribution, movement, population and densities of elephants. However, we sourced information on the densities of elephants in the sub-Saharan region from Thouless et al. (2016). Our review includes English; peer-reviewed articles containing 
original research from 1970 to 2017. This review excludes thesis documents and dissertations. We considered all studies from the four sub-Saharan regions (west, east, south and central Africa).

Relevant articles were identified using different keywords in different databases. Data were sourced from the ISI Web of Science during May 2018. "African elephant" was the first keyword used to retrieve studies published on elephants from the database. Two thousand two hundred and fifty-three $(n=2253)$ studies dating back to 1972 were retrieved. We refined our search using keywords such as "elephant damage", "elephant impact" and "woody vegetation" which resulted in 26 studies that matched these criteria. Since the Web of science database only lists articles between 1972 and 2018, we decided to search other scientific databases.

An additional list of 507 studies was sourced from Nexus, SA e-Publications, EBSCOHost, ScienceDirect, Taylor \& Francis, ProQuest, BioOne, and SpringerLink using the keywords "elephant damage, "elephant impact," "woody vegetation" and "Africa." Studies from these electronic databases, repositories and search engines dated back to 1970, which is two years earlier than the data retrieved from the Web of Science website. Eighty-one $(n=81)$ studies from this search were relevant and were included in this review. Based on all the retrieved studies $(n=2253$ from ISI Web of science +507 from above listed additional databases $=2760$ ), a sample of 106 $(n=26+80=106)$ studies were used for this review paper. These studies matched our search criteria and were grouped according to which part of the sub-Saharan region they belong to (eastern, central, western or southern Africa).

From the 106 studies, we extracted the year of publication, authors, methods used, country and location of the study area, and publishing journal and its location. We broadly recognized two types of methods from these studies, field-based (FB) and remote sensing-based (RS). Field-based methods have been extensively used due to their robustness in providing a widely reliable dataset (Buchanan et al., 2013). According to Liverman et al. (1998), field-based studies are generally not sufficient to quantify and analyze patterns of spatiotemporal change at an aggregated level. On the other hand, remote sensing techniques provide useful data sources for quantitatively measuring the dynamics of change processes at the landscape scale by analyzing change trajectories (Mertens and Lambin, 2000). Since this paper intends to provide insight into the types of methods used by scientists to study the impact of elephants on woody vegetation in Africa, we further discuss the limitations of each of the two approaches (field-based and remote sensing-based).

\section{Content analysis}

We determined the number of studies using either field-based or remote sensingbased methods per African region. Based on Thouless et al. (2016) report that estimated densities of African elephants in sub-Saharan Africa, we compared the relationship between the number of studies and the estimated number of elephants per region. Information on the national affiliation of the lead and the last author (Bhattacharya, 2010) was extracted for each of the studies. We included the lead author on the basis that the first author is generally the person who did most of the work, while the last author was included on the basis that he or she may have contributed to the work as a supervisor affiliated to an academic institution (Bhattacharya, 2010). We further identified the scientific journals that published all the studies included in this review and whether these were local (within African) or international (outside Africa). 


$$
-4049 \text { - }
$$

\section{Results}

For this review, we identified peer-reviewed studies on the impact of African elephants on vegetation in the sub-Sahara region, which is the natural distribution range for African elephants (Thouless et al., 2016) (Fig. 1). A total of $(\mathrm{n}=106)$ papers was retrieved from different scientific databases (Table 1). Eighty-seven percent (87\%) of the studies used field-based methods $(n=92)$ while $13 \%(n=14)$ applied remote sensing-based methods for data collection. A list of all peer-reviewed studies, both field-based and remote sensing-based published between 1970 and 2017 is included as Appendix A. Field-based studies date back to 1970 and the oldest study that used remote sensing data to study elephant impact on vegetation was done in 1997, which is two decades after the field-based studies. A list of the estimated number of elephants (Thouless et al., 2016) for countries in Sub-Saharan Africa is included as Appendix B.

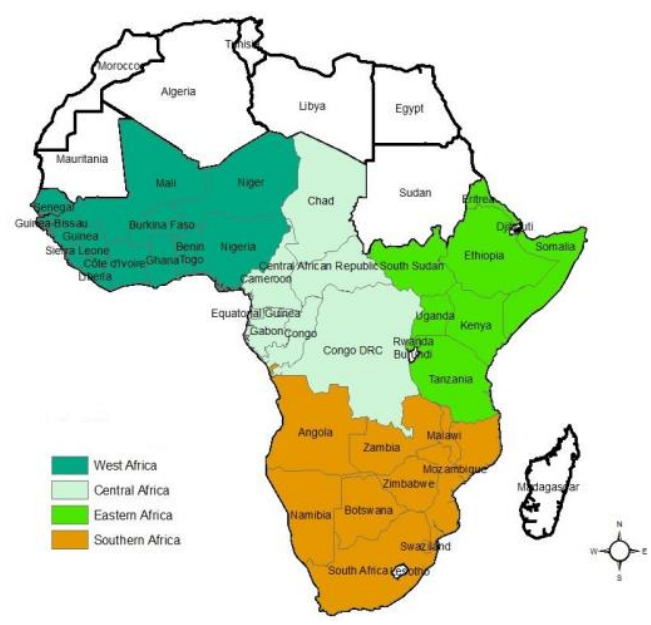

Figure 1. Distribution map of African elephants in the west, east, south and central countries of the sub-Saharan region in Africa (ESRI, 2014)

Table 1. A number of peer-reviewed papers retrieved from different databases

\begin{tabular}{c|c|c}
\hline Database & Retrieved articles & Relevant articles in the sample \\
\hline BioOne & 14 & 7 \\
EBSCOHost & 9 & 5 \\
ISI Web of Science & 2253 & 26 \\
Nexus (NRF Research) & 12 & 12 \\
ProQuest & 49 & 13 \\
SA e-Publications & 55 & 6 \\
ScienceDirect & 203 & 16 \\
SpringerLink & 65 & 10 \\
Taylor \& Francis & 100 & 11 \\
\hline TOTAL & $\mathbf{2 7 6 0}$ & $\mathbf{1 0 6}$ \\
\hline
\end{tabular}

\section{Field-based and remote sensing based methods}

We determined countries with records of field-based and remote sensing-based studies and the number of elephants in each country (Table 2$)$. Ninety-two $(n=92)$ of the field based studies are located in Africa, and one study was done in Gal Oya National Park, Sri Lanka (Ishwaran, 1983). This study is excluded in Table 2 since it was not done in an African park or reserve. Another study area located in East Africa 
was not specific to a particular reserve or national park (Laws, 1970). Since we could not individually assign it to one specific study location, we have also excluded it from Table 2. Fourteen $(n=14)$ remote sensing-based studies were identified, and only one was located in Africa and not specific to a particular reserve or national park (Duffy and Pettorelli, 2012), and is therefore not included in the data represented in Table 2. There is a study that was done in Borgu game reserve, Guinea (Afolayan, 1976) on the impact of elephant activities on woody vegetation, and according to Thouless et al. (2016), there is no record of estimated elephant numbers for the country.

Table 2. List of countries with a record of field-based and remote sensing-based studies and the number of elephants

\begin{tabular}{c|c|c|c|c|c|c}
\hline Region & Country & No. of FB & \% of FB & No. of RS $^{* *}$ & \% of RS $^{* *}$ & No. of elephants \\
\hline West Africa & Burkina Faso & 3 & 3 & 0 & 0 & 6850 \\
West Africa & Benin & 1 & 1 & 0 & 0 & 2984 \\
West Africa & Ghana & 1 & 1 & 0 & 0 & 994 \\
West Africa & Guinea & 1 & 1 & 0 & 0 & 0 \\
Southern Africa & Botswana & 10 & 12 & 5 & 38 & 131626 \\
Southern Africa & Zimbabwe & 20 & 23 & 2 & 15 & 82630 \\
Southern Africa & Zambia & 1 & 1 & 1 & 8 & 21967 \\
Southern Africa & South Africa & 30 & 35 & 3 & 23 & 18841 \\
Southern Africa & Mozambique & 1 & 1 & 0 & 0 & 10884 \\
Southern Africa & Malawi & 1 & 1 & 0 & 0 & 1307 \\
Central Africa & Cameroon & 1 & 1 & 0 & 0 & 6830 \\
Central Africa & Chad & 1 & 1 & 0 & 0 & 794 \\
Eastern Africa & Tanzania & 10 & 12 & 0 & 0 & 50433 \\
Eastern Africa & Kenya & 5 & 6 & 1 & 8 & 22809 \\
Eastern Africa & Uganda & 3 & 3 & 1 & 8 & 4923 \\
Eastern Africa & Rwanda & 1 & 1 & 0 & 0 & 88 \\
\hline \multicolumn{2}{l}{}
\end{tabular}

*Field-based studies, **Remote sensing-based studies

We compared the relationship between the top ten African countries with the highest number of elephants to the number of studies from each one of them (Fig. 2). We also summarised the type of data used in the remote sensing-based studies (Table 3).

\section{Affiliation of the lead and the last author for FB and RS based methods}

The majority of the articles' lead and last authors for both field-based and remote sensing-based methods are affiliated with institutions located in South Africa (26\%). The United States of America follows South Africa with 17\%, United Kingdom and Zimbabwe with 10\%, and the rest of the other countries below 3\% (Fig. 3). There is a relatively equal distribution of lead: last authors ratio affiliations in all the countries, except for Botswana, Netherlands and Uganda with higher numbers of last author affiliations: $3 \%$ : $2 \%$ for Botswana, 1\%: $0 \%$ for the Netherlands and 3\%: $1 \%$ for Uganda.

The highest percentage (6\%) of lead and last authors affiliated with institutions in the United States of America were for studies that used remote sensing-based methods. This is followed by Botswana, South Africa and the United Kingdom with 2\% each and the rest of the other countries at below one percent. Field-based methods were applied to $73 \%$ of the studies compared to $27 \%$ for the remote sensing-based methods (Fig. 4).

All studies, both field-based and remote sensing-based were published in 43 different journals. Eighty-four percent $(n=36)$ were in international journals, and 16\% $(n=7)$ were published in local journals (Table 4). 


$$
-4051-
$$

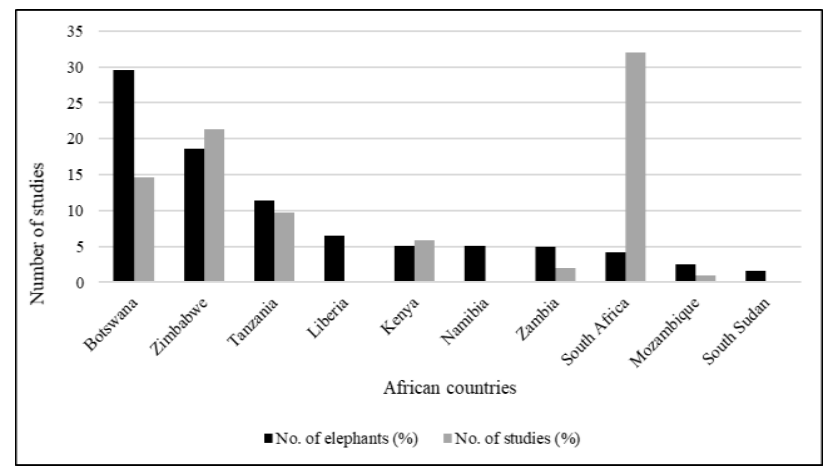

Figure 2. The percentages of field-based and remote sensing-based studies in relation to the estimated percentage of elephants for the top ten African countries

Table 3. Summary of studies that applied the remote sensing-based method and the type of data used

\begin{tabular}{c|c|c|c}
\hline Satellite data & Number of studies & Percentage & Study Objective \\
\hline Landsat TM & 2 & 14 & Impact of management strategies \\
Landsat MSS & 1 & 7 & Vegetation change over time \\
NDVI & 2 & 14 & Greeness versus elephant densities \\
MODIS & 1 & 7 & Piosphere effects \\
3-D & 2 & 14 & Vegetation structure \\
SPOT+NOAA+AVHRR & 1 & 7 & Ecological feature recognition \\
Aerial & 2 & 14 & Vegetation change over time \\
Aerial+SPOT & 1 & 7 & Vegetation change over time \\
Landsat+CORONA & 1 & 7 & Grazing pressures \\
Landsat+ETM+OLI & 1 & $\mathbf{1 0 0}$ & Impact of climate, fire and elephants \\
\hline
\end{tabular}

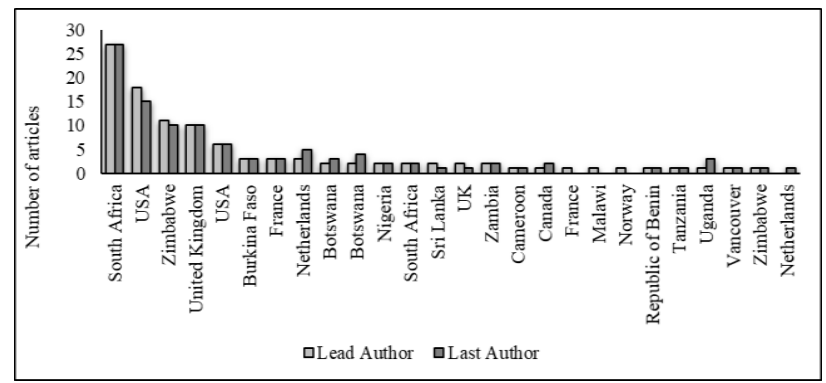

Figure 3. National affiliation of lead and last authors from 106 reviewed papers

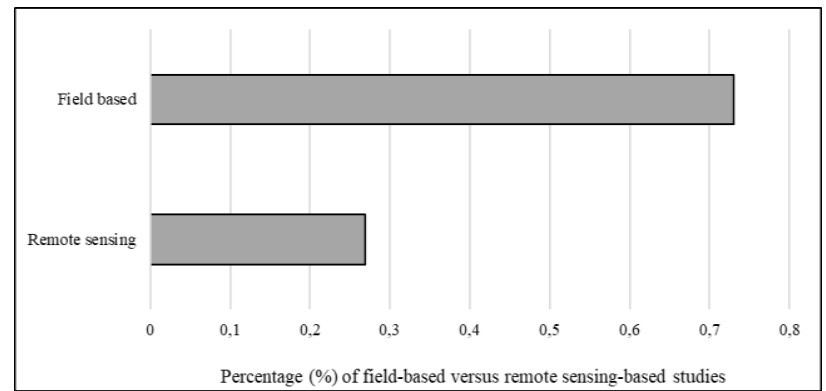

Figure 4. The difference between studies that used field-based and remote sensing-based methods 
Table 4. Names of scientific journals where each of the reviewed studies were published

\begin{tabular}{|c|c|c|c|c|c|c|c|}
\hline & Name of Jnl. & Country & FBO $^{* * *}$ & $\mathbf{R S}^{\text {****}}$ & All studies & Local & Intern." \\
\hline 1 & Jnl. of Tropical Ecology & United States & 13 & 0 & 13 & 0 & 1 \\
\hline 2 & African Jnl. of Ecology & England & 11 & 1 & 12 & 0 & 1 \\
\hline 3 & South African Jnl. of Wildlife Research & South Africa & 7 & 0 & 7 & 1 & 0 \\
\hline 4 & Biological Conservation & England & 5 & 1 & 6 & 0 & 1 \\
\hline 5 & Koedoe & South Africa & 6 & 0 & 6 & 1 & 0 \\
\hline 6 & Ecological Applications & United States & 4 & 0 & 4 & 0 & 1 \\
\hline 7 & Oikos & Denmark & 4 & 0 & 4 & 0 & 1 \\
\hline 8 & Biotropica & United States & 3 & 0 & 3 & 0 & 1 \\
\hline 9 & Ecography & Denmark & 2 & 1 & 3 & 0 & 1 \\
\hline 10 & Ecology & United States & 2 & 1 & 3 & 0 & 1 \\
\hline 11 & Int. Jnl. of Remote Sensing & England & 0 & 3 & 3 & 0 & 1 \\
\hline 12 & South Africa Jnl. of Botany & South Africa & 3 & 0 & 3 & 1 & 0 \\
\hline 13 & Int. Jnl. of Biodiversity and Conservation & $?$ & 2 & 0 & 2 & 0 & 1 \\
\hline 14 & Jnl. of Applied Ecology & England & 1 & 1 & 2 & 0 & 1 \\
\hline 15 & Jnl. of Arid Environments & United States & 2 & 0 & 2 & 0 & 1 \\
\hline 16 & Jnl. of Ecology & England & 2 & 0 & 2 & 0 & 1 \\
\hline 17 & Jnl. of Vegetation Science & England & 2 & 0 & 2 & 0 & 1 \\
\hline 18 & Pachyderm & Kenya & 2 & 0 & 2 & 1 & 0 \\
\hline 19 & South African Jnl. of Science & South Africa & 2 & 0 & 2 & 1 & 0 \\
\hline 20 & Tropical Ecology & India & 2 & 0 & 2 & 0 & 1 \\
\hline 21 & Ambio & Sweden & 1 & 0 & 1 & 0 & 1 \\
\hline 22 & Austral Ecology & Australia & 1 & 0 & 1 & 0 & 1 \\
\hline 23 & Biodiversity and Conservation & Netherlands & 1 & 0 & 1 & 0 & 1 \\
\hline 24 & Conservation Biology & United States & 0 & 1 & 1 & 0 & 1 \\
\hline 25 & Ecological Research & Japan & 1 & 0 & 1 & 0 & 1 \\
\hline 26 & Ecosystems & United States & 1 & 0 & 1 & 0 & 1 \\
\hline 27 & Environmental Modeling and Assessment Jnl. & Australia & 1 & 0 & 1 & 0 & 1 \\
\hline 28 & Forest Ecology and Management & Netherlands & 1 & 0 & 1 & 0 & 1 \\
\hline 29 & International Forestry Review & England & 1 & 0 & 1 & 0 & 1 \\
\hline 30 & Int. Jnl. of Applied Earth Observ. \& Geoinfo & Netherlands & 0 & 1 & 1 & 0 & 1 \\
\hline 31 & Int. Jnl. of Environmental Sciences & England & 1 & 0 & 1 & 0 & 1 \\
\hline 32 & Jnl. of Animal Ecology & England & 1 & 0 & 1 & 0 & 1 \\
\hline 33 & Jnl. of Ecology and the Natural Environment & $?$ & 1 & 0 & 1 & 0 & 1 \\
\hline 34 & Kirkia & Zimbabwe & 1 & 0 & 1 & 1 & 0 \\
\hline 35 & Land & $?$ & 0 & 1 & 1 & 0 & 1 \\
\hline 36 & Plant Ecology & Netherlands & 1 & 0 & 1 & 0 & 1 \\
\hline 37 & $\begin{array}{l}\text { Proceedings of the National Academy of } \\
\text { Sciences }\end{array}$ & USA & 0 & 1 & 1 & 0 & 1 \\
\hline 38 & Regional Environmental Change & $?$ & 0 & 1 & 1 & 0 & 1 \\
\hline 39 & SpringerPlus & Germany & 0 & 1 & 1 & 0 & 1 \\
\hline 40 & Systematics and Geography of Plants & Belgium & 1 & 0 & 1 & 0 & 1 \\
\hline 41 & Transactions of the Royal Society of RSA & South Africa & 1 & 0 & 1 & 1 & 0 \\
\hline 42 & Tropical Pest Management & England & 1 & 0 & 1 & 0 & 1 \\
\hline 43 & Vegetatio / Plant Ecology & United States & 1 & 0 & 1 & 0 & 1 \\
\hline & & & 92 & 14 & 106 & 7 & 36 \\
\hline
\end{tabular}

*International, **Field-based, ***Remote sensing, ?Unknown, Geoinfo-Geoinformation, Int.International, Jnl.-Journal, RSA-Republic of South Africa, Observ.-Observation

\section{Discussion}

Southern Africa has the highest number of elephants on the African continent, with an estimated $71 \%(n=293447)$ of all the elephants on the continent. East Africa has 21\%, Central Africa 6\% and West Africa 3\% (Thouless et al., 2016). The highest estimated elephant distribution range of $1325998 \mathrm{~km}^{2}$ is in southern Africa, followed by $880648 \mathrm{~km}^{2}$ for East Africa, $783085 \mathrm{~km}^{2}$ for Central Africa and $142500 \mathrm{~km}^{2}$ for West Africa.

The top ten countries with the highest number of elephants include Botswana (131 626), Zimbabwe (82 630), Tanzania (50 433), Kenya (22 809), Namibia (22 754), 
Zambia (21 967), South Africa (18 841), Mozambique (10 884), South Sudan (7 103) and Gabon (7 058) (Table 2 and Appendix B).

Our results indicate that South Africa produced the highest number of studies on the impact of elephants on woody vegetation and yet has a lower number of elephants compared to Botswana, Zimbabwe, and Tanzania. Botswana has the highest number of elephants but not as many research studies (15 studies) compared to South Africa (33) and Zimbabwe (22). According to Blanc et al. (2007), elephant numbers are increasing in Southern Africa, which may result in an irreversible impact on vegetation, especially in enclosed protected areas with high elephant densities.

South Africa's elephants are kept in fenced-off protected areas, which necessitates intensive management strategies. There are high levels of concern about how elephants influence vegetation and habitats. This explains the demand for increased research and resulting publications in South Africa. Another factor that could explain why South Africa has the highest number of studies could be that it is the most developed third world country on the continent, compared to for example Botswana. The presence and number of academic institutions, collaborative opportunities, and access to research funding, developed and maintained infrastructure, and a large number of protected areas and national parks all contribute towards the number of publications from the country.

Botswana has an estimated 131626 number of elephants in an area covering approximately $228073 \mathrm{~km}^{2}$. South Africa is home to approximately 18841 elephants in a $30651 \mathrm{~km}^{2}$ area (Thouless et al., 2016). The estimated density of elephants equates to 0.6 individual animals per square kilometer $\left(0.6 / \mathrm{km}^{2}\right)$ for both countries.

\section{Field-based methods}

Field-based methods have been used for many decades in ecological studies. Using field-based methods, information about the extent, spatial variation and resources species preferences by elephants can be studied in detail. Such information is essential for the development of effective management plans for conservation and protected areas. Although FB studies can be impractical and costly when applied in large areas and when large-scale datasets are required on a regular basis, they provide detailed ecological data at smaller scales and need to be simple enough to be widely applied in protected areas with limited capacity (Simms, 2009; Buchanan et al., 2013).

The highest number of studies on African elephants and their influence on vegetation using field-based methods emanated from southern Africa (Table 2). Almost half (48\%) of the field-based studies are from South Africa, 32\% from Zimbabwe and 16\% from Botswana. Although Botswana and adjacent areas have the largest population of elephants in the world (Skarpe et al., 2004), only ten field-based studies on the impact of elephants on vegetation are from Botswana. South Africa and Zimbabwe are the most active countries regarding research on the interaction between elephants and plants, with 30 and 20 field-based studies, respectively (Table 2). The majority of reviewed studies located in South Africa were done in the Kruger National Park $(43 \%, n=13)$ and ten percent each $(n=3)$ were done for both Venetia-Limpopo Nature Reserve and AddoElephant National Park. All field-based studies in Botswana were conducted in the Northern-Botswana area along the Chobe River and Okavango Delta.

The lead and last authors for the field-based methods have affiliations with institutions in South Africa (26\%), the US (17\%) and the UK (10\%). This shows that a significant proportion of field-based research on the impact of elephants is affiliated to Africa, while the US and UK researchers show active involvement. 


\section{Remote sensing-based methods}

Remote sensing techniques are cost-effective for application in large areas for collecting large-scale datasets (Duro et al., 2007). Limitations relate to limited funding to acquire satellite images, facilities, accessibility to data and the skills required to manage such datasets.

Botswana applies remotely sensed data more actively than all other countries in the sub-Saharan region (Table 2). In southern Africa, five out of 13 studies (38\%) who used remotely sensed data were from Botswana, three $(23 \%)$ were from South Africa, two $(15 \%)$ from Zimbabwe and one (8\%) from Zambia. Only one study per country in East Africa (Kenya and Uganda) used remotely sensed data, while there were no such studies from central and West African countries. Thouless et al. (2016) highlight factors that contribute to the accuracy of elephant densities in different countries, which may also influence the probabilities of executing remote-sensing research studies. Some countries may not have the financial means and expertise to conduct systematic elephant censuses on a regular basis, while countries that have political conflicts may not have the time or finances to do these surveys, let alone research.

Multispectral images such as Landsat and SPOT images, Aerial photographs, MODIS and Normalised Difference Vegetation Index (NDVI) were used in 13 remote sensing-based studies. Three of these studies were done in South Africa and were based in the Kruger National Park. One of them used panchromatic aerial photographs and digital SPOT imagery (Munyati and Sinthumule, 2016), while the other two used state of the art hyperspectral satellite imagery to capture the three-dimensional (3D) structure of vegetation (Asner et al., 2009; Levick et al., 2009). Both of the studies used LiDAR imagery to study the large-scale impact of herbivory on the structural diversity of vegetation. Levick et al. (2009) also highlight the value of 3D remote sensing in the assessment of conservation management outcomes.

The lead and last authors for remote sensing-based methods are mostly affiliated with institutions in the USA (6\%), followed by Botswana, South Africa and the UK with $2 \%$ each. The low number of lead and last authors with affiliations in Africa may suggest that foreign institutions have financed the research conducted in Africa. Alternatively, this could relate to a slow transfer pace of technology and skills by developed countries to developing countries.

\section{Publishing scientific journals}

From the 43 scientific journals (Table 4) that published the reviewed studies in this paper, $84 \%(n=36)$ were from outside the African continent, and only $15 \%(n=7)$ were in journals from within Africa. The 14 studies that used remote-sensing data were published in journals outside the African continent, while 22 of the field-based studies were in African journals and 70 in journals outside Africa. The Journal of Tropical Ecology (United States of America - USA) published the highest number of studies ( $n=13$ ) followed by the African Journal of Ecology (England) publishing eleven. Within Africa, 19 of the field-based studies were published in five South African journals (Koedoe, SA Journal of Botany, SA Journal of Science, SA Journal of Wildlife Research and the Transactions of the Royal Society of South Africa), two studies in a Kenyan journal, Pachyderm and one in a Zimbabwean journal, Kirkia. No remote sensing studies were published in any of the African journals. The South African 
Journal of Wildlife Research published the majority of the South African studies $(n=7)$ followed by Koedoe $(n=6)$.

Elephants are major agents of change to woody vegetation as observed in some studies (Anderson and Walker, 1974; Caughley, 1976; Guy, 1976). Despite elephants modifying woody vegetation, Thomson (1992) alluded that no protected area in Africa is big enough to maintain elephants in a healthy state indefinitely without population management manipulation. Culling elephants, as a means of preventing woody vegetation loss is unlikely to produce the desired effects (Ben-Shahar, 1996a) since there is adequate production of browse available for elephants in drought years. The use of contraceptives is impractical for elephant cows due to the requirement for frequent follow-up treatments. Contraceptives are expensive to administer for both elephant cows and bulls. As our protected areas become overpopulated with increasing numbers of elephants, three things are bound to happen: (i) destruction of woodlands that will be replaced by mixed scrubland/grassland or degraded savanna; (ii) a catastrophic crash of elephant populations; and (iii) loss of plants and animals (Thomson, 1992).

Collecting ecological data on a regular basis from large, inaccessible and often dangerous areas (due to the presence of lion, leopard, rhinoceros, buffalo and elephant) using field-based methods can be challenging. Limitations relate to accessing rugged terrain, large areas to traverse, time constraints and financial implications. Using remote sensing techniques integrated with traditional field-based approaches, we can identify the biophysical characteristics of landscapes, predict species distributions, determine spatial variability in species richness, and monitor the impact of species on their environment (Kerr and Ostrovsky, 2003; Kohi et al., 2010) with less time spent in the field. Limitations of remote sensing techniques include the need to be integrated with field-based observations to validate results (Reinke et al., 2006). Collecting remotely sensed data could be very costly, with limited access in some instances. It is crucial to identify appropriate imaging characteristics (such as spatial and spectral resolution) suitable for processing and extracting relevant and vital information (Adam et al., 2010). Garrity et al. (2013) identified a shortcoming in detecting trees that are in various stages of morbidity due to the limited availability of archived satellite imagery. Regardless of the recognized limitations to using remotely sensed data, it is still a valuable tool that continues to prove its potential for use in a wide range of vegetation studies providing timely, up-to-date and accurate information for sustainable and effective management of vegetation (Adam et al., 2010).

We have noted the lack of available published studies on the use of remotely sensed data to map the small-scale impact of African elephant on woody vegetation. Only two reviewed studies used hyperspectral images to determine the large-scale responses of vegetation and ecosystem structure to the presence/absence of herbivory (Asner et al., 2009) and to gain insight into the influence of fire and herbivory to the structure and heterogeneity of savanna vegetation (Levick et al., 2009). Northern Botswana is known to have the highest density of elephants in the world (Skarpe et al., 2004) and the majority of studies from Botswana reported that elephant damage to vegetation is not significant. As noted by Ben-Shahar (1996b), the impact of elephants is generally distributed randomly. Some authors used field-based methods to study the effects of elephants on woodland modification and the implications this has on the diversity of bird species (Herremans, 1995) and the nesting sites of Southern Ground Hornbill (Henley and Henley, 2005). The placement of artificial water points influences tree biomass (Ben-Shahar, 1996a) and structure (Kalwij et al., 2010). Tall tree densities are 
affected by elephants in mopane woodlands (Ben-Shahar, 1998). From these studies, the impact of elephants was not significant, and in other instances, woody biomass and densities remained unchanged, except for new damage to vegetation during the dry season, which was recorded by Ben Shahar (1996b).

\section{Conclusion}

Field-based methods have been extensively used in ecology since the 1960s and are still effectively used. From reviewed studies on the impact of elephants on woody vegetation that applied field-based methods, we have noticed a steady increase from an average of two studies per year before the $20^{\text {th }}$ century, to an average of four studies after the $20^{\text {th }}$ century. These methods provide detailed and reliable datasets. This is an indication that field-based methods are still relevant today, even with advancements in technology in the form of remote sensing techniques.

Remote sensing and GPS technology have also been utilized to track elephant movements (Kahumbu, 2002; Bohrer et al., 2014; Xu et al., 2017). Field-based methods are utilized in combination with remote sensing techniques for field observations. Although remote sensing techniques offer cost-effective and repeatable ways for regular data collection and monitoring for trends, there is also a fieldwork element associated with it. However, using remote sensing techniques, time and labour required for field surveys, especially on an annual basis, are drastically reduced (Jensen, 2005). The results of our reviews indicate that there is a limited amount of studies that used remote sensing-based methods for studying the impact of elephants on woody vegetation. Even the available studies are sparsely distributed between 1997 and 2017, with three studies published in 2009, two of which were done in the Kruger National Park, South Africa and one in Hwange National Park, Zimbabwe.

Guldemond et al. (2017) call for the management of habitats used by elephants to maintain the heterogeneity of Savanna, with particular attention to important tree species of conservation value. These can only be achieved with improved and efficient methods of data collection. Remote sensing techniques can be useful and practical and should be used in conjunction with field-based methods for improved data collection, analyses and interpretation. However, there is a need for the transfer of technology and skills, capacity building and increased support to Africa. Access to quality remotely sensed data needs to be improved to promote the use of this technology and its integration into nature conservation disciplines to address conservation research questions about vegetation trends and responses to impact. Collaborative projects between skilled remote-sensing and field-based researchers are recommended to increase research capacity and the use of technology.

Based on the studies we reviewed our conclusions suggest that the use of remote sensing techniques in studying the impact of elephants on woody vegetation are currently limited. The limited number of studies that applied remote sensing-based methods are in Africa. We therefore encourage the integration of data collected from both remote sensing technology and field-based methods for monitoring the influence of elephants on woody vegetation. Remote sensing techniques are continuously improving and incorporating data collected with the latest technology will enhance habitat management strategies in the future. It is important to highlight that most African countries are in a developmental stage with limited resources and capacity. We also recommend that researchers should take advantage of available novel tools such as 
remote sensing technology to explore its practical and cost-effective applications to managing environments containing elephants, especially in a world that is becoming tech-savvy.

Acknowledgements. We would like to thank Mrs L Adriaanse from UNISA Library Services for providing and sourcing the list of articles from Nexus, SA e-Publications, EBSCOHost, ScienceDirect, Taylor \& Francis, ProQuest, BioOne, and SpringerLink databases. This research did not receive any specific grant from funding agencies in the public, commercial, or not-for-profit sectors. We applied the "sequence-determines-credit approach" (SDC) for authors in this paper.

\section{REFERENCES}

[1] Adam, E., Mutanga, O., Rugege, D. (2010): Multispectral and hyperspectral remote sensing for identification and mapping of wetland vegetation: A review. - Wetlands Ecology and Management 18(3): 281-296.

[2] Afolayan, T. A. (1976): Habitat utilisation by elephant in the Guinea zone. Commonwealth Forestry Review 55(1): 65-71.

[3] Anderson, G. D., Walker, B. H. (1974): Vegetation composition and elephant damage in the Sengwa Wildlife Research Area, Rhodesia. - Journal of the Southern African Wildlife Management Association 4(1963): 1-14.

[4] Asner, G. P., Levick, S. R., Kennedy-Bowdoin, T., Knapp, D. E., Emerson, R., Jacobson, J., Colgan, M. S., Martin, R. E. (2009): Large-scale impacts of herbivores on the structural diversity of African savannas. - Proceedings of the National Academy of Sciences 106(12): 4947-4952.

[5] Balfour, D., Peel, M., Killian, H., Little, R., Smit, I., Garai, M., Henley, M. (2008): Controlling the distribution of elephant. - Assessment of South African Elephant Management (2nd Draft): 1-51.

[6] Baxter, P. W. J., Getz, W. M. (2008): Development and parameterization of a rain- and fire-driven model for exploring elephant effects in African savannas. - Environmental Modeling and Assessment 13(2): 221-242.

[7] Ben-Shahar, R. (1996a): Do elephants over-utilize mopane woodlands in northern Botswana? - Journal of Tropical Ecology 12(4): 505-515.

[8] Ben-Shahar, R. (1996b): Woodland dynamics under the influence of elephants and fire in Northern Botswana. - Vegetatio 123(2): 153-163.

[9] Ben-Shahar, R. (1998): Changes in the structure of savanna woodlands in northern Botswana following the impacts of elephants and fire. - Plant Ecology 136: 189-194.

[10] Bhattacharya, S. (2010): Authorship issue explained. - Indian Journal of Plastic Surgery 43(2): 233-234.

[11] Blanc, J. J., Barnes, R. F. W., Craig, G. C., Dublin, H. T., Thouless, C. R., Hart, J. A. (2007): African Elephant Status Report 2007: An update from the African Elephant Database Africa. - IUCN, Gland, Switzerland.

[12] Bohrer, G., Beck, P. S. A., Ngene, S. M., Skidmore, A. K., Douglas-Hamilton, I. (2014): Elephant movement closely tracks precipitation-driven vegetation dynamics in a Kenyan forest-savanna landscape. - Movement Ecology 2(2): 1-12.

[13] Buchanan, G. M., Fishpool, L. D. C., Evans, M. I., Butchart, S. H. M. (2013): Comparing field-based monitoring and remote-sensing, using deforestation from logging at Important Bird Areas as a case study. - Biological Conservation 167: 334-338.

[14] Burt, W. H. (1943): Territoriality and home range concepts as applied to mammals. Journal of Mammalogy 24: 346-352.

[15] Caughley, G. (1976): The elephant problem - an alternative hypothesis. - East African Wildlife Journal 14(4): 265-283. 
[16] De Boer, F., Kohi, E. (2008): Positive Aspects of Elephants - an Experiment. - Siyabona Africa. Retrieved from http://www.krugerpark.co.za/krugerpark-times-e-2-positiveaspects-of-elephants-25008.html.

[17] Dublin, H. T., Sinclair, A. R. E., McGlade, J. (1990): Elephants and Fire as Causes of Multiple Stable States in the Serengeti-Mara Woodlands. - Journal of Animal Ecology 59(3): 1147-1164.

[18] Duffy, J. P., Pettorelli, N. (2012): Exploring the relationship between NDVI and African elephant population density in protected areas. - African Journal of Ecology 50(4): 455463.

[19] Duro, D. C., Coops, N. C., Wulder, M. A., Han, T. (2007): Development of a large area biodiversity monitoring system driven by remote sensing. - Progress in Physical Geography 31(3): 235-260.

[20] ESRI. (2014): ArcGIS Desktop: Release 10.2.1. - Redlands, CA: Environmental Systems Research Institute.

[21] Ferguson, A. J. (2014): High elephant impact is capable of converting tall mopane woodland to shrubland in the South East Lowveld of Zimbabwe. - Thesis. University of Cape Town.

[22] Gadd, M. E. (2002): The impact of elephants on the marula tree Sclerocarya birrea. African Journal of Ecology 40: 328-336.

[23] Gandiwa, E., Kativu, S. (2009): Influence of fire frequency on Colophospermum mopane and Combretum apiculatum woodland structure and composition in northern Gonarezhou National Park, Zimbabwe. - Koedoe 51(1): 1-13.

[24] Gandiwa, E., Magwati, T., Zisadza, P., Chinuwo, T., Tafangenyasha, C. (2011): The impact of African elephants on Acacia tortilis woodland in northern Gonarezhou National Park, Zimbabwe. - Journal of Arid Environments 75(9): 809-814.

[25] Garrity, S. R., Allen, C. D., Brumby, S. P., Gangodagamage, C., McDowell, N. G., Cai, D. M. (2013): Quantifying tree mortality in a mixed species woodland using multitemporal high spatial resolution satellite imagery. - Remote Sensing of Environment 129: 54-65.

[26] Grainger, M., Van Aarde, R., Whyte, I. (2005): Landscape heterogeneity and the use of space by elephants in the Kruger National Park, South Africa. - African Journal of Ecology 43: 369-375.

[27] Guldemond, R. A. R. (2006): The influence of savanna elephants on vegetation: a case study in the Tembe Elephant Park, South Africa. - University of Pretoria.

[28] Guldemond, R. A., Van Aarde, R. J. (2008): A Meta-Analysis of the Impact of African Elephants on Savanna Vegetation. - Journal of Wildlife Management 72(4): 892-899.

[29] Guldemond, R. A. R., Purdon, A., Van Aarde, R. J. (2017): A systematic review of elephant impact across Africa. - PLoS ONE 12(6): 1-12.

[30] Guy, P. R. (1976): The feeding behaviour of elephant (Loxodonta africana) in the Sengwa Area, Rhodesia. - South African Journal of Wildlife Research 6(1): 55-63.

[31] Hamandawana, H. (2012): The impacts of herbivory on vegetation in Moremi Game Reserve, Botswana: 1967-2001. - Regional Environmental Change 12(1): 1-15.

[32] Henley, M., Henley, S. (2005): The potential influence of elephants on Southern Ground Hornbill nesting sites. Southern Ground Hornbill, Bucorvus Leadbeateri, Population and Habitat Viability Assessment (PHVA) Briefing Book, (January 2005). - Retrieved from http://files/1121/Henly \& Henly unpublished report.pdf.

[33] Herremans, M. (1995): Effects of woodland modification by African elephant Loxodonta africana on bird diversity in northern Botswana. - Ecography 18(4): 440-454.

[34] Ishwaran, N. (1983): Elephant and woody-plant relationships in Gal Oya, Sri Lanka. Biological Conservation 26(3): 255-270.

[35] Jensen, J. R. (2005): Introductory digital image processing. - Upper Saddle River, NJ: Pearson Prentice-Hall. 
[36] Kahumbu, P. G. (2002): The effects of elephants on their habitat in the Shimba Hills, Kenya. - Thesis. Princeton University.

[37] Kalwij, A. J. M., Boer, W. F., De Mucina, L., Prins, H. H. T., Skarpe, C., Winterbach, C. (2010): Tree cover and biomass increase in a southern African savanna despite growing elephant population. - Ecological Applications 20(1): 222-233.

[38] Kelly, H. L. P. (2000): The effect of Elephant Utilization on the Sterculia rogersii and Adansonia digitata Populations of the Kruger National Park. - Thesis. University of Pretoria, Pretoria.

[39] Kerr, J. T., Ostrovsky, M. (2003): From space to species: ecological applications for remote sensing. - Trends in Ecology \& Evolution 18(6): 299-305.

[40] Kohi, E. M., de Boer, W. F., Peel, M. J. S., Slotow, R., van der Waal, C., Heitkönig, I. M. A., Skidmore, A., Prins, H. H. T. (2011): African Elephants Loxodonta africana Amplify Browse Heterogeneity in African Savanna. - Biotropica 43(6): 711-721.

[41] Laws, A. R. M. (1970): Elephants as Agents of Habitat and Landscape Change in East Africa. - Oikos 21(1): 1-15.

[42] Levick, S. R., Asner, G. P., Kennedy-Bowdoin, T., Knapp, D. E. (2009): The relative influence of fire and herbivory on savanna three-dimensional vegetation structure. Biological Conservation 142(8): 1693-1700.

[43] Liverman, D., Moran, E. F., Rindfuss, R. R., Stern, P. C. (1998): People and pixels: linking remote sensing and social science. - Washington, DC.: National Academy Press.

[44] Lotter, H., Henley, M., Fakir, S., Pickover, M., Ramose, M. (2008): Ethical considerations in elephant management. - Elephant Management: A Scientific Assessment for South Africa, (January 2008): 406-445.

[45] Mackey, R. L., Page, B. R., Duffy, K. J., Slotow, R. (2006): Modelling elephant population growth in small, fenced, South Africa reserves. - South African Journal of Wildlife Research 36: 33-43.

[46] Mertens, B., Lambin, E. F. (2000): Land-Cover-Change Trajectories in Southern Cameroon. - Annals of the Association of the American Geographers 90(3): 467-494.

[47] Mondol, S., Moltke, I., Hart, J., Keigwin, M., Brown, L., Stephens, M., Wasser, S. K. (2015): New evidence for hybrid zones of forest and savanna elephants in Central and West Africa. - Molecular Ecology 24(24): 6134-6147.

[48] Munyati, C., Sinthumule, N. I. (2016): Change in woody cover at representative sites in the Kruger National Park, South Africa, based on historical imagery. - SpringerPlus 5(1): $1-23$.

[49] Nowak, R. M. (1999): Walker's Mammals of the World. - Baltimore and London: The Johns Hopkins University Press.

[50] Pimm, S. L., Van Aarde, R. J. (2001): African elephants and immunocontraception. Nature 411: 766.

[51] Poole, J. H. (1993): Kenya's initiatives in elephant fertility regulation and population control techniques. - Pachyderm 16: 62-65.

[52] Raath, J. P. (1999): Relocation of African elephants. - In: Fowler, M. E., Miller, R. E. (eds.) Zoo and wildlife medicine: Current therapy (4th ed., pp. 525-532). Philadelphia, PA, Saunders.

[53] Reinke, K., Reinke, L., Jones, S., Jones, S. (2006): Integrating vegetation field surveys with remotely sensed data. - Journal of Applied Remote Sensing 7: 18-23.

[54] Rubio-Martínez, L. M., Hendrickson, D. A., Stetter, M., Zuba, J. R., Marais, H. J. (2014): Laparoscopic Vasectomy in African Elephants (Loxodonta africana). - Veterinary Surgery 43(5): 507-514.

[55] Ruggiero, R. G. (1992): Seasonal forage intake by elephants in central Africa. - African Journal of Ecology 30: 137-148.

[56] Shannon, G., Thaker, M., Vanak, A. T., Page, B. R., Grant, R., Slotow, R. (2011): Relative Impacts of Elephant and Fire on Large Trees in a Savanna Ecosystem. Ecosystems 14(8): 1372-1381. 
[57] Simms, C. (2009): The utilisation of satellite images for the detection of elephant induced vegetation change patterns. - Thesis. University of South Africa, Johannesburg.

[58] Skarpe, C., Aarrestad, P. A., Andreassen, H. P., Dhillion, S. S., Dimakatso, T., du Toit, J. T., Halley, D. J., Hytteborn, H., Makhabu, S., Mari, M., Marokane, W., Masunga, G., Modise, D., Moe, S. R., Mojaphoko, R., Mosugelo, D., Mptsumi, S., Neo-Mahupeleng, G., Ramotadima, M., Rutina, L., Sechele, L., Sejoe, T. B., Stokke, S., Swenson, J. E., Taolo, C., Vandewalle, M., Wegge, P. (2004): The return of the giants: ecological effects of an increasing elephant population. - Ambio 33(6): 276-282.

[59] Smit, I. P. J., Ferreira, S. M. (2010): Management intervention affects river-bound spatial dynamics of elephants. - Biological Conservation 143(9): 2172-2181.

[60] Thomson, R. (1992): The Wildlife Game (1st ed.). - Westville, South Africa: The Nyala Wildlife Publications Trust.

[61] Thouless, C. R., Dublin, H. T., Blanc, J. J., Skinner, D. P., Daniel, T. E., Taylor, R. D., Maisels, F., Frederick, H. L., Bouché, P. (2016): African Elephant Status Report: An update from the African Elephant Database. - IUCN, Gland, Switzerland.

[62] Van Aarde, R. J., Jackson, T. P., Ferreira, S. M. (2006): Conservation science of elephant management in southern Africa. - South African Journal of Science 102: 385-388.

[63] Van Aarde, R. J., Jackson, T. P. (2007): Megaparks for metapopulations: addressing the cause of locally high elephant numbers in southern Africa. - Biological Conservation 134: 289-297.

[64] Van Staden, P. J., Bezuidenhout, H., Ferreira, S., Bredenkamp, G. J. (2016): The effects of elephants and fire on vegetation at Marakele National Park, South Africa. - Pachyderm 58: 107-122.

[65] Whyte, I., Grobler, D. (1998): Elephant contraception research in the Kruger National Park. - Pachyderm 25: 45-52.

[66] Whyte, I., Van Aarde, R. J., Pimm, S. L. (1998): Managing the elephants of Kruger National Park. - Animal Conservation 1: 77-83.

[67] Wiseman, R. (2001): Woody vegetation change in response to browsing in Ithala Game Reserve, South Africa. - University of Cape Town.

[68] Xie, Y., Sha, Z., Yu, M. (2008): Remote sensing imagery in vegetation mapping: a review. - Journal of Plant Ecology-Uk 1(1): 9-23.

[69] Xu, W., Fayrer-Hosken, R., Madden, M., Simms, C., Mu, L., Presotto, A. (2017): Coupling African elephant movement and habitat modelling for landscape availabilitysuitability-connectivity assessment in Kruger National Park. - Pachyderm 58: 97-106.

[70] Zimmerman, T. D. (2014): Field-based Data Collection. - In: Gunstone, R. (ed.) Encyclopedia of Science Education. Springer, Dordrecht.

\section{APPENDIX A}

\section{A list of peer-reviewed studies published between 1970 and 2017}

Studies that used remote sensing-based methods:

[1] Asner, G. P., Levick, S. R., Kennedy-Bowdoin, T., Knapp, D. E., Emerson, R., Jacobson, J., Colgan, M. S., Martin, R. E. (2009): Large-scale impacts of herbivores on the structural diversity of African savannas. - Proceedings of the National Academy of Sciences 106(12): 4947-4952.

[2] Chamaille-Jammes, S., Fritz, H., Madzikanda, H. (2009): Piosphere contribution to landscape heterogeneity: a case study of remote-sensed woody cover in a high elephant density landscape. - Ecography 32(5): 871-880.

[3] Duffy, J. P., Pettorelli, N. (2012): Exploring the relationship between NDVI and African elephant population density in protected areas. - African Journal of Ecology 50(4): 455463. 


$$
-4061-
$$

[4] Fox, J., Vandewalle, M., Alexander, K. (2017): Land Cover Change in Northern Botswana: The Influence of Climate, Fire, and Elephants on Semi-Arid Savanna Woodlands. - Land 6(4): 1-23.

[5] Hamandawana, H. (2012): The impacts of herbivory on vegetation in Moremi Game Reserve, Botswana: 1967-2001. - Regional Environmental Change 12(1): 1-15.

[6] Levick, S. R., Asner, G. P., Kennedy-Bowdoin, T., Knapp, D. E. (2009): The relative influence of fire and herbivory on savanna three-dimensional vegetation structure. Biological Conservation 142(8): 1693-1700.

[7] Mackey, R. L., Page, B. R., Duffy, K. J., Slotow, R. (2006): Modelling elephant population growth in small, fenced, South Africa reserves. - South African Journal of Wildlife Research 36: 33-43.

[8] Munyati, C., Sinthumule, N. I. (2016): Change in woody cover at representative sites in the Kruger National Park, South Africa, based on historical imagery. - SpringerPlus 5(1): $1-23$.

[9] Murwira, A., Skidmore, A. K., Huizing, H. J. G., Prins, H. H. T. (2010): Remote sensing of the link between arable field and elephant (Loxodonta africana) distribution change along a tsetse eradication gradient in the Zambezi valley, Zimbabwe. - International Journal of Applied Earth Observation and Geoinformation 12(1): 123-130.

[10] Rasmussen, H. B., Wittemyer, G., Douglas-Hamilton, I. (2006): Predicting time-specific changes in demographic processes using remote-sensing data. - Journal of Applied Ecology 43(2): 366-376.

[11] Ringrose, S., Vanderpost, C., Matheson, W. (1997): Use of image processing and GIS techniques to determine the extent and possible causes of land management/fenceline induced degradation problems in the Okavango area, northern Botswana. - International Journal of Remote Sensing 18(11): 2337-2364.

[12] Ringrose, S., Vanderpost, C., Matheson, W. (2003): Mapping ecological conditions in the Okavango Delta, Botswana using fine and coarse resolution systems including simulated SPOT vegetation imagery. - International Journal of Remote Sensing 24(5): 1029-1052.

[13] Robinson, J. A., Lulla, K. P., Kashiwagi, M., Suzuki, M., Nellis, M. D., Bussing, C. E., Lee Long, W. J., McKenzie, L. J. (2001): Conservation applications of astronaut photographs of earth: Tidal-flat loss (Japan), elephant effects on vegetation (Botswana), and seagrass and mangrove monitoring (Australia). - Conservation Biology 15(4): 876884.

[14] Yang, J., Prince, S. D. (2000): Remote sensing of savanna vegetation changes in Eastern Zambia 1972-1989. - International Journal of Remote Sensing 21(2): 301-322.

\section{Studies that used field-based methods:}

[1] Afolayan, T. A. (1975): Effects of Elephant Activities on Forest Plantations in the Kilimanjaro Forest-Game Reserve in Northern Tanzania. - Oikos 26(3): 405-410.

[2] Afolayan, T. A. (1976): Habitat utilisation by elephant in the Guinea zone. Commonwealth Forestry Review 55(1): 65-71.

[3] Anderson, G. D., Walker, B. H. (1974): Vegetation composition and elephant damage in the Sengwa Wildlife Research Area, Rhodesia. - Journal of the Southern African Wildlife Management Association 4(1963): 1-14.

[4] Aristide, T. C., Eric, K., Apolinaire, M. G., Marcel, H., Brice, S. A. (2012): Identification and characterization of vegetation exploited by the elephant Loxodonta africana in the Pendjari Biosphere Reserve in the North-West region of Benin. - Pachyderm 52: 36-48.

[5] Augustine, D., Mcnaughton, S. (2010): Regulation of shrub ungulates by native browsing dynamics Regulation on East African rangeland. - Journal of Applied Ecology 41(1): 4558.

[6] Barnes, R. F. W. (1982): Elephant feeding behaviour in Ruaha National Park, Tanzania. African Journal of Ecology 20(2): 123-136. 
[7] Barnes, R. F. W. (1983): The Elephant Loxodonta africana problem in Ruaha National Park Tanzania. - Biological Conservation 26(1983): 127-148.

[8] Baxter, P. W. J., Getz, W. M. (2005): A model-framed evaluation of elephant effects on tree and fire dynamics in African savannas. - Ecological Applications 15(4): 1331-1341.

[9] Baxter, P. W. J., Getz, W. M. (2008): Development and parameterization of a rain- and fire-driven model for exploring elephant effects in African savannas. - Environmental Modeling and Assessment 13(2): 221-242.

[10] Ben-Shahar, R. (1993): Patterns of elephant damage to vegetation in northern Botswana. - Biological Conservation 65(3): 249-256.

[11] Ben-Shahar, R. (1996a): Do elephants over-utilize mopane woodlands in northern Botswana? - Journal of Tropical Ecology 12(4): 505-515.

[12] Ben-Shahar, R. (1996b): Woodland dynamics under the influence of elephants and fire in Northern Botswana. - Vegetatio 123(2): 153-163.

[13] Ben-Shahar, R. (1998): Changes in the structure of savanna woodlands in northern Botswana following the impacts of elephants and fire. - Plant Ecology 136: 189-194.

[14] Ben-Shahar, R. (1998): Elephant density and impact on Kalahari woodland habitats. Transactions of the Royal Society of South Africa 53(2): 149-155.

[15] Botha, J., Witkowski, E. T. F., Shackleton, C. M. (2002): A comparison of anthropogenic and elephant disturbance on Acacia xanthophloea (fever tree) populations in the Lowveld, South Africa. - Koedoe 45(1): 9-18.

[16] Boundja, R. P., Midgley, J. J. (2010): Patterns of elephant impact on woody plants in the Hluhluwe-Imfolozi Park, Kwazulu-Natal, South Africa. - African Journal of Ecology 48(1): 206-214.

[17] Calenge, C., Maillard, D., Gaillard, J.-M., Merlot, L., Peltier, R. (2002): Elephant damage to trees of wooded savanna in Zakouma National Park, Chad. - Journal of Tropical Ecology 18(04): 599-614.

[18] Chafota, J., Owen-Smith, N. (2009): Episodic severe damage to canopy trees by elephants: interactions with fire, frost and rain. - Journal of Tropical Ecology 25(03): 341-345.

[19] Coetsee, C., Wigley, B. J. (2016): Browser impacts in Mapungubwe National Park, South Africa: Should we be worried? - Koedoe 58(1): 1-10.

[20] Coetzee, B. J., Engelbrecht, A. H., Joubert, S. C. J., Retief, P. F. (1979): Elephant impact on Sclerocarya caffra trees in Acacia nigrescens tropical plains thornveld of the Kruger National Park. - Koedoe 22(1): 36-60.

[21] Coverdale, T. C., Kartzinel, T. R., Grabowski, K. L., Shriver, R. K., Hassan, A. A., Goheen, J. R., Palmer, T. M., Pringle, R. M. (2016): Elephants in the understory: Opposing direct and indirect effects of consumption and ecosystem engineering by megaherbivores. - Ecology 97(11): 3219-3230.

[22] Cumming, D. H. M., Fenton, M. B., Rautenbach, I. L., Taylor, R. D., Cumming, G. S., Cumming, M. S., Dunlop, J. M., Ford, G. S., Hovorka, M. D., Johnston, D. S., Kalcounis, M. C., Mhlanga, Z., Portfors, C. V. (1997): Elephants, woodlands and biodiversity in Southern Africa. - South African Journal of Science 93(January 2016): 231-236.

[23] Dublin, H. T., Sinclair, A. R. E., McGlade, J. (1990): Elephants and Fire as Causes of Multiple Stable States in the Serengeti-Mara Woodlands. - Journal of Animal Ecology 59(3): 1147-1164.

[24] Duffy, K. J., van Os, R., Vos, S., van Aarde, J., Ellish, G. (2002): Estimating impact of reintroduced elephant on trees in a small reserve. - South African Journal of Wildlife Research 32(1): 23-29.

[25] Gadd, M. E. (2002): The impact of elephants on the marula tree Sclerocarya birrea. African Journal of Ecology 40: 328-336.

[26] Gandiwa, E., Magwati, T., Zisadza, P., Chinuwo, T., Tafangenyasha, C. (2011): The impact of African elephants on Acacia tortilis woodland in northern Gonarezhou National Park, Zimbabwe. - Journal of Arid Environments 75(9): 809-814. 
[27] Guy, P. R. (1976): The feeding behaviour of elephant (Loxodonta africana) in the Sengwa Area, Rhodesia. - South African Journal of Wildlife Research 6(1): 55-63.

[28] Guy, P. R. (1989): The Influence of Elephants and Fire on a Brachystegia julbernardia Woodland in Zimbabwe. - Journal of Tropical Ecology 5(2): 215-226.

[29] Hawthorne, W. D., Parren, M. P. E. (2000): How Important Are Forest Elephants to the Survival of Woody Plant Species in Upper Guinean Forests? - Journal of Tropical Ecology 16(1): 133-150.

[30] Helm, C. V., Witkowski, E. T. F., Kruger, L., Hofmeyr, M., Owen-Smith, N. (2009): Mortality and utilisation of Sclerocarya birrea subsp. caffra between 2001 and 2008 in the Kruger National Park, South Africa. - South African Journal of Botany 75(3): 475484.

[31] Helm, C., Wilson, G., Midgley, J., Kruger, L., Witkowski, E. T. F. (2011): Investigating the vulnerability of an African savanna tree (Sclerocarya birrea ssp. caffra) to fire and herbivory. - Austral Ecology 36(8): 964-973.

[32] Hema, E. M., Barnes, R. F. W., Di Vittorio, M., Luiselli, L., Guenda, W. (2017): Selective disturbance by elephants (Loxodonta africana) on eight tree species in a West African savanna. - Ecological Research 32(2): 205-214.

[33] Herremans, M. (1995): Effects of woodland modification by African elephant Loxodonta africana on bird diversity in northern Botswana. - Ecography 18(4): 440-454.

[34] Hiscocks, K. A. Y. (1999): The impact of an increasing elephant population on the woody vegetation in southern Sabi Sand Wildtuin, South Africa. - Koedoe 42(2): 47-55.

[35] Holdo, R. M. (2003): Woody plant damage by African elephants in relation to leaf nutrients in western Zimbabwe. - Journal of Tropical Ecology 19(2): 189-196.

[36] Holdo, R. M., McDowell, L. R. (2004): Termite Mounds as Nutrient-Rich Food Patches for Elephants. - Biotropica 36(2): 231-239.

[37] Holdo, R. M. (2006): Elephant herbivory, frost damage and topkill in Kalahari sand woodland savanna trees. - Journal of Vegetation Science 17(4): 509-518.

[38] Holdo, R. M. (2006): Tree growth in an African woodland savanna affected by disturbance. - Journal of Vegetation Science 17(3): 369-378.

[39] Holdo, R. M. (2007): Elephants, fire, and frost can determine community structure and composition in Kalahari woodlands. - Ecological Applications 17(2): 558-568.

[40] Holdo, R. M., Holt, R. D., Fryxell, J. M. (2009): Grazers, Browsers, and Fire Influence the Extent and Spatial Pattern of Tree Cover in the Serengeti. - Ecological Applications 19(1): 95-109.

[41] Höft, R., Höft, M. (1995): The differential effects of elephants on rainforest communities in the Shimba Hills, Kenya. - Biological Conservation 73(1): 67-79.

[42] Hrabar, H., Hattas, D., du Toit, J. T. (2009): Differential effects of defoliation by mopane caterpillars and pruning by African elephants on the regrowth of Colophospermum mopane foliage. - Journal of Tropical Ecology 25(03): 301-309.

[43] Ishwaran, N. (1983): Elephant and woody-plant relationships in Gal Oya, Sri Lanka. Biological Conservation 26(3): 255-270.

[44] Jachmann, H., O’Donoghue, M., Rood, K. (1989): Influence of Fire on Elephant Use of Combretum / Terminalia Woodland in Southern Burkina Faso. - Oikos 54(3): 310-314.

[45] Jachmann, H., Croes, T. (1991): Effects of browsing by elephants on the Combretum/Terminalia woodland at the Nazinga Game Ranch, Burkina Faso, West Africa. - Biological Conservation 57(1): 13-24.

[46] Jacobs, O. S., Biggs, R. (2002): The status and population structure of the marula in the Kruger National Park. - South African Journal of Wildlife Research 32(1): 1-12.

[47] Johnson, C. F., Cowling, R. M., Phillipson, P. B. (1999): The flora of the Addo Elephant National Park, South Africa: Are threatened species vulnerable to elephant damage? Biodiversity and Conservation 8(11): 1441-1456. 
[48] Kalwij, A. J. M., Boer, W. F., De Mucina, L., Prins, H. H. T., Skarpe, C., Winterbach, C. (2010): Tree cover and biomass increase in a southern African savanna despite growing elephant population. - Ecological Applications 20(1): 222-233.

[49] Kerley, G. I. H., Landman, M. (2006): The impacts of elephants on biodiversity in the Eastern Cape Subtropical Thickets. - South African Journal of Science 102(9-10): 395402.

[50] Kohi, E. M., de Boer, W. F., Peel, M. J. S., Slotow, R., van der Waal, C., Heitkönig, I. M. A., Skidmore, A., Prins, H. H. T. (2011): African Elephants Loxodonta africana Amplify Browse Heterogeneity in African Savanna. - Biotropica 43(6): 711-721.

[51] Kupika, O. L., Kativu, S., Gandiwa, E., Gumbie, A. (2014): Impact of African elephants on baobab (Adansonia digitata L.) population structure in northern Gonarezhou National Park, Zimbabwe. - Tropical Ecology 55(2): 159-166.

[52] Landman, M., Gaylard, A., Mendela, T., Kerley, G. I. H. (2005): Impact of elephant on two woody trees, Boscia oleoides and Pappea capensis, in an arid thicket-Nama Karoo mosaic, Greater Addo Elephant National Park. - Koedoe 56(1): 1-3.

[53] Laws, A. R. M. (1970): Elephants as Agents of Habitat and Landscape Change in East Africa. - Oikos 21(1): 1-15.

[54] Laws, R. M., Parker, I. S. C., Johnstone, R. C. B. (1970): Elephants and habitats in North Bunyoro, Uganda. - African Journal of Ecology 8(1970): 163-180.

[55] Lewis, D. M. (1991): Observations of tree growth, woodland structure and elephant damage on Colophospermum mopane in Luangwa Valley, Zambia. - African Journal of Ecology 29(3): 207-221.

[56] Löyttyniemi, K., Mikkola, L. (1980): Elephant as a pest of pines in zambia. - Tropical Pest Management 26(2): 167-169.

[57] MacGregor, S. D., O'Connor, T. G. (2004): Response of Acacia tortilis to utilization by elephants in a semi-arid African savanna. - South African Journal of Wildlife Research 34(1): 55-66.

[58] Mapaure, I., Mhlanga, L. (2000): Patterns of elephant damage to Colophospermum mopane on selected Islands in Lake Kariba, Zimbabwe. - Kirkia 17(2): 189-198.

[59] Mapaure, I. (2001): Small-scale variations in species composition of Miombo woodland in Sengwa, Zimbabwe: the influence of edaphic factors, fire and elephant herbivory. Systematics and Geography of Plants 71(2): 935-947.

[60] Mapaure, I. (2013): A preliminary simulation model of individual and synergistic impacts of elephants and fire on the structure of semi-arid miombo woodlands in northwestern Zimbabwe. - Journal of Ecology and the Natural Environment 5(10): 285-302.

[61] Moncrieff, G. R., Kruger, L. M., Midgley, J. J. (2008): Stem mortality of Acacia nigrescens induced by the synergistic effects of elephants and fire in Kruger National Park, South Africa. - Journal of Tropical Ecology 24(06): 655-662.

[62] Morrison, T. A., Holdo, R. M., Anderson, T. M. (2016): Elephant damage, not fire or rainfall, explains mortality of overstorey trees in Serengeti. - Journal of Ecology 104(2): 409-418.

[63] Mukwashi, K., Gandiwa, E., Kativu, S. (2012): Impact of African elephants on Baikiaea plurijuga woodland around natural and artificial watering points in northern Hwange National Park, Zimbabwe. - Agris On-Line Papers in Economics and Informatics 2(3): $1355-1368$.

[64] Nasseri, N. A., Mcbrayer, L. D., Schulte, B. S. (2011): The impact of tree modification by African elephant (Loxodonta africana) on herpetofaunal species richness in northern Tanzania. - African Journal of Ecology 49: 133-140.

[65] Ndoro, O., Mashapa, C., Kativu, S., Gandiwa, E. (2016): Impact of African elephant on baobab along a surface water availability gradient in Mana Pools National Park, Zimbabwe. - Tropical Ecology 57(2): 333-341. 
[66] Nellemann, C., Moe, S. R., Rutina, L. P. (2002): Links between terrain characteristics and forage patterns of elephants (Loxodonta africana) in northern Botswana. - Journal of Tropical Ecology 18(06): 835-844.

[67] Parker, D. M. (2017): The composition and complexity of the woody and succulent components of Albany thicket with and without elephants. - South African Journal of Botany 112: 19-28.

[68] Pellegrini, A. F. A., Pringle, R. M., Govender, N., Hedin, L. O. (2017): Woody plant biomass and carbon exchange depend on elephant-fire interactions across a productivity gradient in African savanna. - Journal of Ecology 105(1): 111-121.

[69] Plumptre, A. J. (1994): The effects of trampling damage by herbivores on the vegetation of the Parc National des Volcans, Rwanda. - African Journal of Ecology 32(2): 115-129.

[70] Pringle, R. M. (2008): Elephants as Agents of Habitat Creation for Small Vertebrates at the Patch Scale. - Ecology 89(1): 26-33.

[71] Ribeiro, N. S., Shugart, H. H., Washington-Allen, R. (2008): The effects of fire and elephants on species composition and structure of the Niassa Reserve, northern Mozambique. - Forest Ecology and Management 255(5-6): 1626-1636.

[72] Ruess, R. W., Halter, F. L. (1990): The impact of large herbivores on the Seronera woodlands, Serengeti National Park, Tanzania. - African Journal of Ecology 28: 259-275.

[73] Seloana, M. Q., Potgieter, M. J., Kruger, J. W., Jordaan, J. J. (2016): The ecological impact of elephant herbivory on vegetation of Atherstone Collaborative Nature Reserve, Limpopo Province, South Africa. - South African Journal of Botany 103: 348.

[74] Seloana, M., Kruger, J. W., Potgieter, M. J., Jordaan, J. J. (2017): Elephant damage to Sclerocarya birrea on different landscapes. - International Journal of Biodiversity and Conservation 9(4): 97-106.

[75] Shannon, G., Druce, D. J., Page, B. R., Eckhardt, H. C., Grant, R., Slotow, R. (2008): The utilization of large savanna trees by elephant in southern Kruger National Park. - Journal of Tropical Ecology 24(03): 281-289.

[76] Shannon, G., Thaker, M., Vanak, A. T., Page, B. R., Grant, R., Slotow, R. (2011): Relative Impacts of Elephant and Fire on Large Trees in a Savanna Ecosystem. Ecosystems 14(8): 1372-1381.

[77] Sharam, G., Sinclair, A. R. E., Turkington, R. (2006): Establishment of Broad-leaved Thickets in Serengeti, Tanzania: The Influence of Fire, Browsers, Grass Competition, and Elephants. - Biotropica 38(5): 599-605.

[78] Skarpe, C., Aarrestad, P. A., Andreassen, H. P., Dhillion, S. S., Dimakatso, T., du Toit, J. T., Halley, D. J., Hytteborn, H., Makhabu, S., Mari, M., Marokane, W., Masunga, G., Modise, D., Moe, S. R., Mojaphoko, R., Mosugelo, D., Mptsumi, S., Neo-Mahupeleng, G., Ramotadima, M., Rutina, L., Sechele, L., Sejoe, T. B., Stokke, S., Swenson, J. E., Taolo, C., Vandewalle, M., Wegge, P. (2004): The return of the giants: ecological effects of an increasing elephant population. - Ambio 33(6): 276-282.

[79] Smallie, J. J., O’Connor, T. G. (2000): Elephant utilization of Colophospermum mopane: possible benefits of hedging. - African Journal of Ecology 38(4): 352-359.

[80] Staub, C. G., Binford, M. W., Stevens, F. R. (2013): Elephant Browsing in Majete Wildlife Reserve, South-western Malawi. - African Journal of Ecology 51: 536-543.

[81] Steyn, A., Stalmans, M. (2001): Selective habitat utilisation and impact on vegetation by African elephant within a heterogeneous landscape. - Koedoe 44(1): 95-104.

[82] Struhsaker, T. T., Lwanga, J. S., Kasenene, J. M. (1996): Elephants, Selective Logging and Forest Regeneration in the Kibale Forest, Uganda. - Journal of Tropical Ecology 12(1): 45-64.

[83] Tedonkeng Pamo, E., Tchamba, M. N. (2001): Elephants and vegetation change in the Sahelo-Soudanian region of Cameroon. - Journal of Arid Environments 48(3): 243-253.

[84] Thomson, P. J. (1975): The role of elephants, fire and other agents in the decline of a Brachystegia boehmii woodland. - Journal of the Southern African Wildlife Management Association 5(1): 11-18. 


$$
-4066-
$$

[85] Tweheyo, M., Tumusiime, D. M., Muhairwe, T., Twinomuhangi, R. (2013): Elephant damage and tree response in restored parts of Kibale National Park, Uganda. International Journal of Biodiversity and Conservation 5(6): 371-377.

[86] Valeix, M., Fritz, H., Dubois, S. E., Kanengoni, K., Alleaume, S., Sad, S. (2007): Vegetation structure and ungulate abundance over a period of increasing elephant abundance in Hwange National Park, Zimbabwe. - Journal of Tropical Ecology 23: 8793.

[87] Van de Vijver, C. A. D. M., Foley, C. A., Olff, H. (1999): Changes in the Woody Component of an East African Savanna During 25 Years. - Journal of Tropical Ecology 15(5): 545-564.

[88] Van Staden, P. J., Bezuidenhout, H., Ferreira, S., Bredenkamp, G. J. (2016): The effects of elephants and fire on vegetation at Marakele National Park, South Africa. - Pachyderm 58(July 2016): 107-122.

[89] Vanak, A. T., Shannon, G., Thaker, M., Page, B., Grant, R., Slotow, R. (2012): Biocomplexity in large tree mortality: Interactions between elephant, fire and landscape in an African savanna. - Ecography 35(4): 315-321.

[90] Vesey-FitzGerald, D. F. (1973): Animal Impact on Vegetation and Plant Succession in Lake Manyara National Park, Tanzania. - Oikos 24(2): 314-324.

[91] Vogel, S. M., Henley, M. D., Rode, S. C., van de Vyver, D., Meares, K. F., Simmons, G., De Boer, W. F. (2014): Elephant (Loxodonta africana) impact on trees used by nesting vultures and raptors in South Africa. - African Journal of Ecology 52: 458-465.

[92] Wiseman, R., Page, B. R., O'Connor, T. G. (2004): Woody vegetation change in response to browsing in Ithala Game Reserve, South Africa. - South African Journal of Wildlife Research 34(1): 25-37.

\section{APPENDIX B}

\begin{tabular}{|c|c|c|c|}
\hline & Region & Country & Number of elephants \\
\hline 1 & Southern Africa & Botswana & 131626 \\
\hline 2 & Southern Africa & Zimbabwe & 82630 \\
\hline 3 & East Africa & Tanzania & 50433 \\
\hline 4 & East Africa & Kenya & 22809 \\
\hline 5 & Southern Africa & Namibia & 22754 \\
\hline 6 & Southern Africa & Zambia & 21967 \\
\hline 7 & Southern Africa & South Africa & 18841 \\
\hline 8 & Southern Africa & Mozambique & 10884 \\
\hline 9 & East Africa & South Sudan & 7103 \\
\hline 10 & Central Africa & Gabon & 7058 \\
\hline 11 & West Africa & Burkina Faso & 6850 \\
\hline 12 & Central Africa & Cameroon & 6830 \\
\hline 13 & Central Africa & Congo & 6057 \\
\hline 14 & East Africa & Uganda & 4923 \\
\hline 15 & Southern Africa & Angola & 3396 \\
\hline 16 & West Africa & Benin & 2984 \\
\hline 17 & Central Africa & DRC & 1794 \\
\hline 18 & Southern Africa & Malawi & 1307 \\
\hline 19 & East Africa & Etiophia & 1017 \\
\hline 20 & West Africa & Ghana & 994 \\
\hline 21 & Central Africa & Equatorial Guinea & 884 \\
\hline 22 & Central Africa & Chad & 794 \\
\hline 23 & Central Africa & Central African Republic & 702 \\
\hline 24 & West Africa & Mali & 253 \\
\hline 25 & West Africa & Cote D'ivoire & 189 \\
\hline 26 & West Africa & Liberia & 124 \\
\hline 27 & West Africa & Nigeria & 94 \\
\hline 28 & East Africa & Rwanda & 88 \\
\hline 29 & Southern Africa & Swaziland & 42 \\
\hline & & & 415427 \\
\hline
\end{tabular}

